\title{
Kajian Kerentanan Pantai terhadap Pengembangan Wilayah Pesisir Pangandaran
}

\author{
Witanto Agung Prayogi*, Yuli Asyiawati \\ Prodi Teknik Perencanaan Wilayah \& Kota, Fakultas Teknik, \\ Universitas Islam Bandung, Indonesia. \\ *witanto.prayogi@gmail.com, jully.asyiawati89
}

\begin{abstract}
The coastal area of Pangandaran is a dynamic area, which is a southern coastal area, making this area also vulnerable to the activities of the Indo-Autralian tectonic plate. This causes the Pangandaran coastal area to be vulnerable to the threat of natural disasters in the form of tidal flooding, abrasion, earthquakes and tsunamis. This study aims to identify the level of coastal vulnerability and the impact of coastal vulnerability on regional development in the Pangandaran coastal area. The analytical method used in this research is multi-disaster vulnerability analysis which is carried out using overlay, scoring and weighting techniques. The parameters used in this analysis are disaster vulnerability from the physical aspects of the influence of sea and land, social and economic factors. The results showed that the study area had a low level of vulnerability of $50.02 \%$, a medium vulnerability of $36.97 \%$, and a high level of vulnerability of $13.01 \%$. This has an impact on the development of community socio-economic activities in the Pangandaran coastal area, especially for the development of tourism, trade and service activities. From the results of the analysis, there are several things that can be recommended from this study, namely (1) planning based on disaster mitigation; (2) improve disaster mitigation support facilities; (3) mitigation education to reduce community losses; (4) provide disaster evacuation sites in areas of low vulnerability.
\end{abstract}

Keywords: Regional Vulnerability, Natural Disasters, Multi-Disaster, and Spatial Planning

Abstrak. Wilayah pesisir Pangandaran merupakan wilayah yang dinamis, yang merupakan wilayah pesisir selatan menjadikan kawasan ini juga rentan terhadap aktivitas terkonik lempeng bumi IndoAutrali. Hal ini menyebabkan wilayah pesisir Pangandaran rentan terhadap ancaman bencana alam berupa banjir rob, abrasi, gempa bumi dan tsunami. Studi ini bertujuan mengidentifikasi tingkat kerentanan pantai dan dampak kerentanan pantai terhadap pengembangan wilayah di wilayah pesisir Pangandaran. Metode analisis yang digunakan dalam penelitian ini adalah analisis kerentanan multibencana yang dilakukan denga teknik overlay, skoring dan pembobotan. Parameter yang digunakan dalam analisis ini yang menjadi kerentanan bencana dari aspek fisik dari pengaruh laut dan darat, faktor sosial dan ekonomi. Hasil penelitian diperoleh bahwa wilayah studi memiliki tingkat kerentanan rendah sebesar 50.02\%, kerentanan sedang 36.97\%, dan tingkat kerentanan tinggi sebesar $13.01 \%$. Hal ini memberikan dampak terhadap pengembangan kegiatan sosial ekonomi masyarakat di wilayah pesisir pangandaran, terutama untuk pengembangan kegiatan wisata, perdagangan dan jasa. Dari hasil analisis tersebut ada beberapa yang dapat direkomendasikan dari kajian ini adalah (1) perencanaan berbasis mitigasi bencana; (2) meningkatkan fasilitas penunjang mitigasi bencana; (3) edukasi mitigasi untuk mengurangi kerugian masyarakat; (4) menyediakan tempat evakuasi bencana pada kawasan tingkat kerentanan rendah.

Kata Kunci: Kerentanan wilayah, Bencana Alam, Multibencana, dan Tata Ruang 


\section{A. Pendahuluan}

Wilayah pesisir merupakan wilayah yang sangat rentan terhadap tekanan lingkungan baik yang berasal dari laut maupun dari darat. Salah satunya adalah adanya kenaikan muka air laut. Dengan meningkatnya aktivitas dan peradaban manusia, maka gas rumah kaca akan terus meningkat yang dapat menyebabkan terjadinya pemanasan global sehingga suhu bumi menjadi meningkat dan mengakibatkan melelehnya es dikutub bumi sehingga menyebabkan terjadinya kenaikan muka laut. Menurut Aldrian dkk,(2011) laju rata-rata kenaikan paras muka laut global adalah $5-10 \mathrm{~mm}$ per tahun. Erosi pantai merupakan dampak adanya akibat kenaikan muka air laut terutama pada wilayah pantai dengan karakteristik pasir atau pantai lumpur yang menyebabkan pergeseran garis pantai (Alibasyah dan Karim 2013)

Selain kerentanan terhadap perubahan iklim kawasan pesisir juga rentan terhadap ancaman bencana geologi seperti tsunami khususnya pantai selatan Pulau Jawa karena berada pada zona rawan gempa bumi akibat tumbukan antara lempeng samudra Indo-Australia dengan lempeng benua Eurasia. Interaksi kedua lempeng tersebut pernah terjadi pada masa lalu dan akan terjadi juga di masa mendatang, sehingga gempa bumi dan tsunami di pantai selatan Pulau Jawa dapat kembali terjadi setiap saat (LIPI, 2007).

Implikasi dari kerentanan pantai di wilayah pesisir Pangandaran pada dasarnya berdasarkan fenomena alam yang terjadi yang dapat menimbulkan bencana alam yang tidak saja merubah struktur dan pola pemanfaatan ruang wilayah, tetapi juga akan berakibat pada perubahan aktivitas sosial dan ekonomi masyarakat pesisir Pangandaran. Untuk mengantisipasi terjadinya pengembangan wilayah yang dilakukan secara sporadis perlu dilakukan kajian mengenai Kerentanan Pantai untuk dapat mewujudkan pengembangan wilayah secara berkelanjutan di wilayah pesisir Pangandaran terutama WP II, hal ini diharapkan dapat meningkatkan pendapatan daerah maupun warga sekitar terutama pada sektor pariwisata yang berwawasan mitigasi bencana.

Upaya mempertahankan fungsi kawasan lindung dapat dilakukan untuk mengontrol perkembangan tata guna lahan dikawasan rawan bencana, agar kerugian fisik yang ditimbulkan jika bencana banjir terjadi kembali tidak terlalu tinggi (Garia dan Asyiawati 2018).

Berdasarkan latar belakang yang telah diuraikan, maka perumusan masalah dalam penelitian ini sebagai berikut: (1) Bagaimana tingkat kerentanan pantai di wilayah pesisir Pangandaran? (2) Bagaimana implikasi pengembangan wilayah pesisir pangandaran terhadap ancaman kerentanan pantai?. Tujuan dalam penelitian ini yaitu (1) Mengidentifikasi tingkat kerentanan pantai di wilayah pesisir Pangandaran (2) Mengidentifikasi dampak kerentanan pantai terhadap pengembangan wilayah

\section{B. Metodologi Penelitian}

\section{Identifikasi Jenis Ancaman Bencana Alam}

1. Rawan Bencana Gelombang Tinggi dan Abrasi

Metode CVI digunakan sebagai Analisa tingkat kerentanan pantai terhadap ancaman kerusakan di wilayah pesisir akibat ancaman bencana gelombang dan abrasi. Rumus CVI:

$$
C V I=\left(\frac{\sqrt{a} \times b \times c \times d \times e \times f \times g}{n}\right)
$$

Keterangan:

$\mathrm{a}=$ Geomorfologi

$\mathrm{b}=$ Perubahan garis pantai

$\mathrm{c}=$ Elevasi

$\mathrm{d}=$ Rata-rata tunggang pasang surut

$\mathrm{e}=$ Kenaikan muka laut relative

$\mathrm{f}=$ Tinggi gelombang signifikan

$\mathrm{g}=$ Geologi

$\mathrm{n}=$ Banyak data

2. Rawan Bencana Gempa Bumi 
Analisis yang dilakukan terhadap kerentanan bencana gempa bumi yaitu skoring dan pembobotan pada argis.

$$
\text { KRB gempabumi } *(60 \%)+\text { Jenis geologi } *(40 \%)
$$

3. Rawan Bencana Tsunami

Analisis yang dilakukan terhadap kerentanan bencana gempa bumi yaitu skoring dan pembobotan pada argis.

$$
\begin{aligned}
& \text { Jarak dari garis pantai } *(30 \%)+\text { Elevasi } *(30 \%)+\text { Slope* }(20 \%)+\text { Jarak dari sungai } \\
& *(10 \%)+\text { Jenis geologi } *(10 \%)
\end{aligned}
$$

\section{Analisis Multi Bencana}

Setelah dilakukan analisis ancaman bencana gelombang tinggi dan abrasi, tsunami, dan gempa bumi selanjutnya dilakukan pemetaan multi bencana. Mengacu pada PERKA BNPB No. 2

\begin{tabular}{|c|c|c|c|c|c|}
\hline \multirow{2}{*}{ No } & \multirow{2}{*}{ Jenis Ancaman } & \multirow{2}{*}{ Bobot (\%) } & \multicolumn{3}{|c|}{ Nilai Skor } \\
\hline & & & Rendah & Sedang & Tinggi \\
\hline 1 & Gelombang tinggi dan abrasi & 0.3238 & \multirow{4}{*}{1} & \multirow{4}{*}{2} & \multirow{4}{*}{3} \\
\hline 2 & Gempa bumi & 0.3664 & & & \\
\hline 3 & Tsunami & 0.3238 & & & \\
\hline \multicolumn{2}{|c|}{ Total } & 1.0 & & & \\
\hline
\end{tabular}
Tahun 2012, bobot setiap bencana untuk pemetaan multi bencana dapat dilihat pada tabel.

Tabel 1. Bobot Ancaman Bencana Alam

Sumber: Olahan Perka BNPB Tahun 2012

\section{Analisis Tingkat Kerentanan}

Analisis tingkat kerentanan bencana menggunakan teknik pembobotan dari Peraturan Kepala Badan Nasional Penanggulangan Bencana No.2 Tahun 2012 tentang Pedoman Umum

\begin{tabular}{|c|c|c|c|c|}
\hline \multirow{2}{*}{$\begin{array}{c}\text { Parameter } \\
\text { Kerentanan } \\
\text { (bobot) }\end{array}$} & \multirow[b]{2}{*}{ Indikator (Bobot) } & \multicolumn{3}{|c|}{ Kelas } \\
\hline & & $\begin{array}{c}\text { Rendah } \\
\text { (1) }\end{array}$ & $\begin{array}{l}\text { Sedang } \\
\text { (2) }\end{array}$ & $\begin{array}{c}\text { Tinggi } \\
\text { (3) }\end{array}$ \\
\hline \multirow[t]{5}{*}{$\begin{array}{c}\text { Kerentanan } \\
\text { Sosial (40) } \\
\end{array}$} & Kepadatan Penduduk (50) & $<500 \mathrm{~J} / \mathrm{km} 2$ & $\begin{array}{c}500-1000 \\
\mathrm{~J} / \mathrm{km} 2\end{array}$ & $>1000 \mathrm{~J} / \mathrm{km} 2$ \\
\hline & Rasio perempuan (10) & $<20 \%$ & $20-40 \%$ & $>40 \%$ \\
\hline & Rasio usia rentan (10) & $<20 \%$ & $20-40 \%$ & $>40 \%$ \\
\hline & Rasio penduduk miskin (10) & $<20 \%$ & $20-40 \%$ & $>40 \%$ \\
\hline & Rasio orang cacat (10) & $<20 \%$ & $20-40 \%$ & $>40 \%$ \\
\hline & Tingkat Pendidikan (10) & Lulus SMA & Lulus SMP & Lulus SD/Tidak Sekolah \\
\hline \multirow{2}{*}{$\begin{array}{c}\text { Kerentanan } \\
\text { ekonomi (25) }\end{array}$} & Lahan produktif $(60)$ & $<30 \%$ & $30-50 \%$ & $>50 \%$ \\
\hline & Rasio jenis Pekerjaan (40) & $\begin{array}{c}\text { Pegawai } \\
\text { Negeri Sipil }\end{array}$ & Swasta & Buruh/Kuli \\
\hline \multirow{2}{*}{$\begin{array}{l}\text { Kerentanan Fisik } \\
\text { (25) }\end{array}$} & Kepadatan bangunan (40) & $<40 \%$ & $40-60 \%$ & $>60 \%$ \\
\hline & Fasiitas umum/kritis (30) & Tersedia RS & $\begin{array}{l}\text { Tersedia } \\
\text { puskesma } \\
\text { s/pustu }\end{array}$ & Tidak tersedia fasilitas \\
\hline
\end{tabular}
Pengkajian Resiko bencana.

Tabel 2. Bobot Kerentanan Wilayah 


\begin{tabular}{|c|l|c|c|c|}
\hline \multirow{4}{*}{$\begin{array}{c}\text { Parameter } \\
\text { Kerentanan } \\
(\text { bobot) }\end{array}$} & \multicolumn{1}{|c|}{ Indikator (Bobot) } & $\begin{array}{c}\text { Kendah } \\
(\mathbf{1})\end{array}$ & $\begin{array}{c}\text { Sedang } \\
\mathbf{( 2 )}\end{array}$ & $\begin{array}{c}\text { Tinggi } \\
\mathbf{( 3 )}\end{array}$ \\
\cline { 2 - 5 } & Aksesibilitas (30) & $\begin{array}{c}\text { Tersedia } \\
\text { Jalan } \\
\text { arteri/kolektor }\end{array}$ & $\begin{array}{c}\text { Tersedia } \\
\text { jalan lokal }\end{array}$ & Tdk ada akses \\
\hline \multirow{3}{*}{$\begin{array}{c}\text { Kerentanan } \\
\text { Lingkungan } \\
(10)\end{array}$} & Luas hutan lindung (40) & $<20 \mathrm{Ha}$ & $20-50 \mathrm{Ha}$ & $>50 \mathrm{Ha}$ \\
\cline { 2 - 5 } & Luas hutas alam/rakyat (30) & $<25 \mathrm{Ha}$ & $25-75 \mathrm{Ha}$ & $>75 \mathrm{Ha}$ \\
\cline { 2 - 5 } & Luas hutan Mangrove (20) & $<10 \mathrm{Ha}$ & $10-30 \mathrm{Ha}$ & $>30 \mathrm{Ha}$ \\
\cline { 2 - 5 } & Luas semak belukar (10) & $<10 \mathrm{Ha}$ & $10-30 \mathrm{Ha}$ & $>30 \mathrm{Ha}$ \\
\hline
\end{tabular}

Sumber: Perka BNPB 2012, Arifin 2010, Muawanah 2016.

Tabel 3. Interval Skoring Tingkat Kerentanan Wilayah

\begin{tabular}{|c|c|c|c|}
\hline Kerentanan & Tingkat Kerentanan & Nilai Terendah & Nilai Tertinggi \\
\hline \multirow{3}{*}{ Kerentanan Sosial } & Rendah & 0.49 & 0.69 \\
\cline { 2 - 4 } & Sedang & 0.79 & 0.99 \\
\cline { 2 - 4 } & Tinggi & 1.00 & 1.29 \\
\hline \multirow{3}{*}{ Kerentanan Ekonomi } & Rendah & 0.25 & 0.42 \\
\cline { 2 - 4 } & Sedang & 0.43 & 0.59 \\
\cline { 2 - 4 } & Tinggi & 0.60 & 0.75 \\
\hline \multirow{3}{*}{ Kerentanan Fisik } & Rendah & 0.25 & 0.42 \\
\cline { 2 - 4 } & Sedang & 0.43 & 0.59 \\
\cline { 2 - 4 } & Tinggi & 0.60 & 0.75 \\
\hline \multirow{3}{*}{ Kerentanan Lingkungan } & Rendah & 0.10 & 0.17 \\
\cline { 2 - 4 } & Sedang & 0.18 & 0.3 \\
\cline { 2 - 4 } & Tinggi & 0.25 & 0.24 \\
\hline
\end{tabular}

Sumber: Hasil Analisis, 2021

Tabel 4. Interval Skoring Kerentanan Wilayah Total

\begin{tabular}{|c|c|c|}
\hline Kerentanan & Nilai Terendah & Nilai Tertinggi \\
\hline Rendah & 1 & 1.59 \\
\hline Sedang & 1.60 & 2.59 \\
\hline Tinggi & 2.60 & 3.00 \\
\hline
\end{tabular}

Sumber: Hasil Analisis, 2021

\section{Analisis terhadap Tata Ruang}

Analisis secara spasial dilakukan dengan melakukan overlay antara peta kerentanan pantai terhadap pola ruang. Tujuan dari analisis ini adalah untuk mengidentifikasi sebaran wilayah kerentanan pantai dengan implikasinya terhadap arah tata ruang dan pengembangan wilayah Kabupaten Pangandaran.

\section{Analisis Identifikasi Dampak Eksisting}

Analisis identifikasi dampak eksisting dilakukan untuk mengetahui dampak kerentanan pantai yang ditimbulkan maka dilakukan overlay peta kerentanan terhadap penggunaan lahan eksisting sehingga dapat diketahui luasan tingkat kerentanan terhadap kondisi saat ini. 


\section{Hasil Penelitian dan Pembahasan}

\section{Ancaman Bencana Alam}

1. Ancaman Bencana Gelombang Tinggi dan Abrasi

Tingkat kerentanan terhadap bencana tinggi gelobang dan abrasi pada wilayah kajian memiliki kerentanan sedang terdapat di seluruh wilayah studi dengan persentase sebesar $70.49 \%$. hal tersebut di karenakan oleh homogenitas parameter dari oseanografi yang digunakan pada analisis ini. Tingkat kerentanan rendah pada wilayah kajian memiliki persentase $20.89 \%$. Sedangkan wilayah dengan tingkat kerentanan tinggi memiliki persentase sebesar $8.66 \%$. Wilayah dengan kerentanan tinggi dipengaruhi tutupan lahan yang banyak digunakan sebagai pemukiman yang menyebabkan kelas kerentanan pada geomorfologi menjadi tinggi. Selain itu ketinggian wilayah yang rendah (0-5 Mdpl) sehingga meningkatkan faktor kerentanan wilayah tersebut.

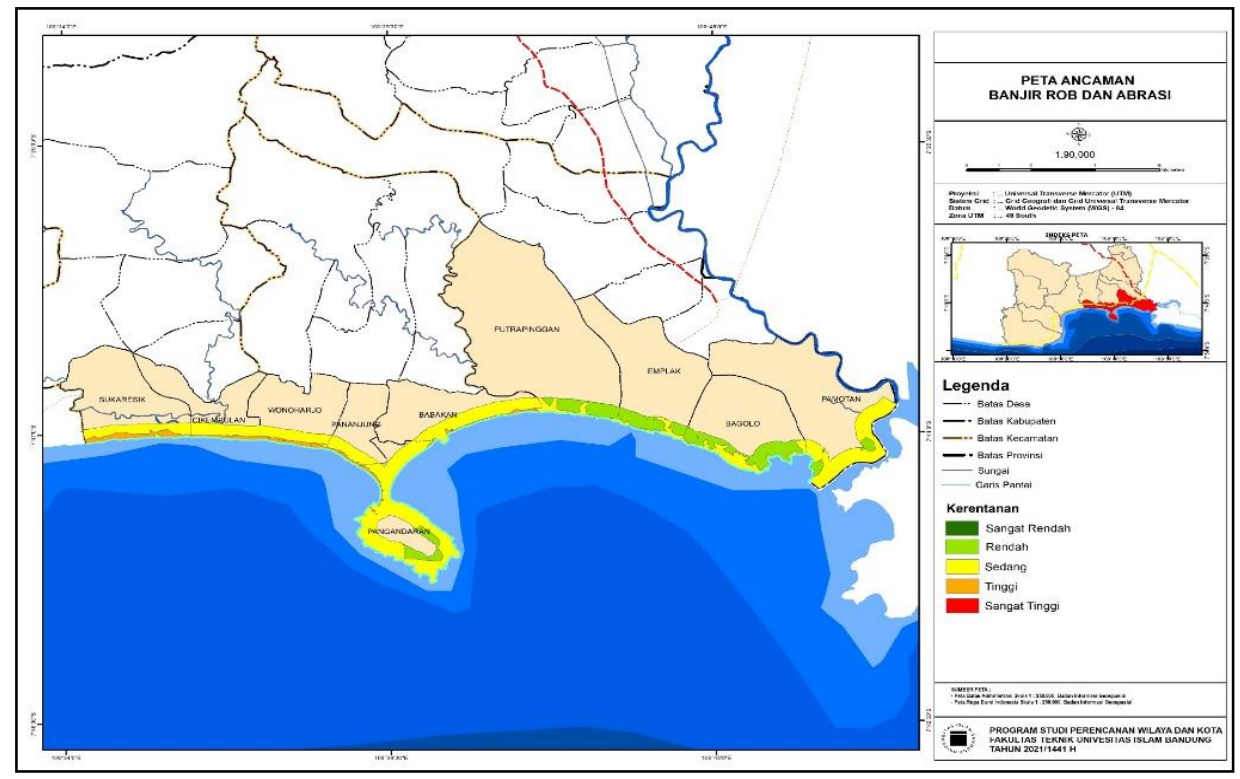

Gambar 1. Ancaman Gelombang Tinggi dan abrasi

\section{Ancaman Gempa Bumi}

Tingkat kerentanan gempabumi di wilayah kajian terbagi menjadi 2 kelas yaitu kelas kerentanan Sedang dan Tingggi. Desa Bagolo, Desa Cikembulan, Desa Emplak, Desa Pamotan dan Desa Putrapinggan memiliki tigkat ancaman bahaya gempa bumi sedang pada keseluruhan wilayahnya, sedangkan Desa Sukaresik dan Desa Wonoharjo memiliki wilayah dengan tingkat ancaman tinggi. Pada wilayah kajian tingkat ancaman bencana gempa bumi dengan kategori sedang memiliki persentase yang lebih besar yaitu sebesar $76.08 \%$ dengan luas total 7051.49 Ha. 


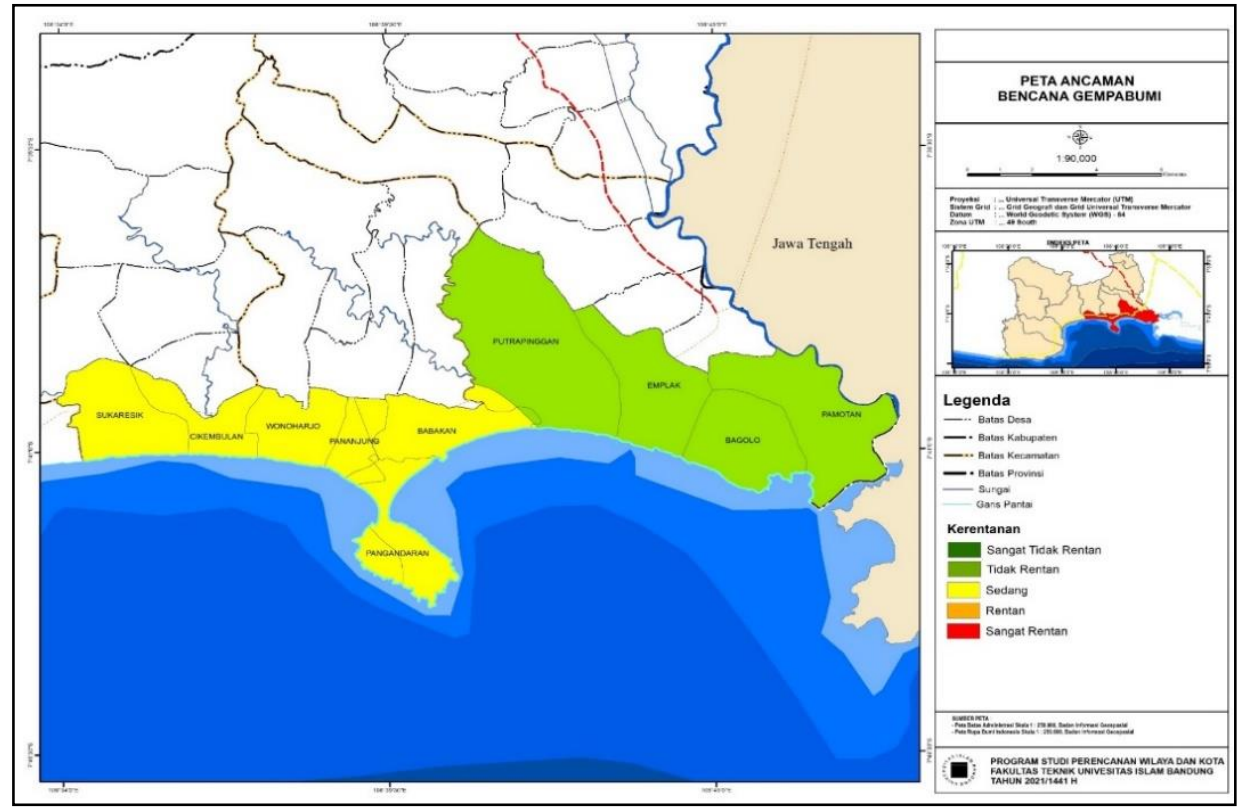

Gambar 2. Ancaman Gempa Bumi

3. Ancaman Tsunami

Berdasarkan hasil analisis diketahui bahwa wilayah studi memiliki wilayah dengan ketegori kerentanan yang sangat tinggi terhadap ancaman bencana tsunami sebesar $16.57 \%$ atau 1526.95 Ha dari total luas wilayah studi. Sedangkan wilayah dengan kategori kerentanan tinggi memiliki persentase $19.72 \%$. Wilayah dengan kategori kerentanan tinggi dan sangat tinggi sebagian besar kelas rentan dan sangat rentan sebagian besar terdapat di Desa Sukaresik, Desa Cikembulan, Desa Wonoharjo, Desa Pananjung, Desa Pangandaran, Desa Babakan dan Desa Pamotan.

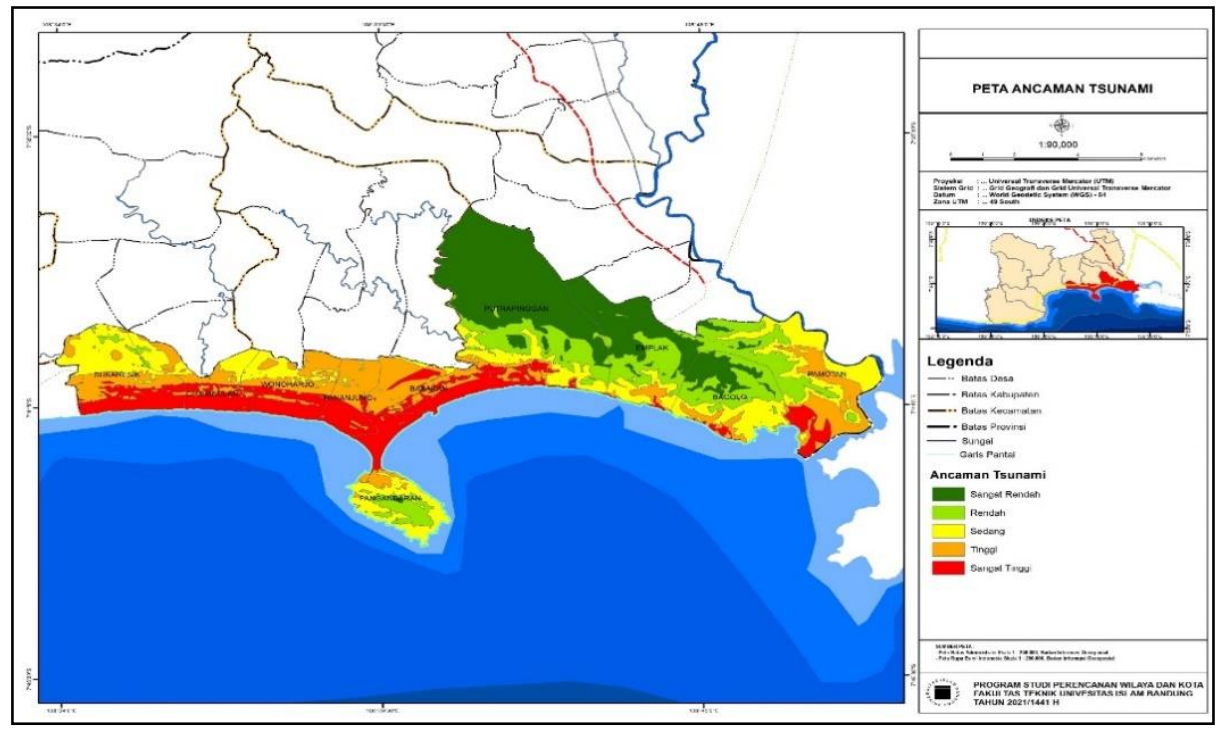

Gambar 3. Ancaman Tsunami 


\section{Pemetaan Multi Bencana}

Berdasarkan hasil analisis didapat bahwa ancaman terhadap multibencana di wilayah studi memiliki kategori tinggi sebesar $11.68 \%$ dan kategori sangat tinggi dengan persentase $5.01 \%$. Wilayah dengan kategori ancaman sangat tinggi mendominasi wilayah di Desa Sukaresik, Desa Cikembulan, Desa Wonoharjo, serta Desa Pananjung. Wilayah dengan tingkat ancaman tinggi dan sangat tinggi secara keseluruhan merupakan wilayah yang langsung berbatasan dengan garis pantai, karena wilayah tersebut sangat rentan terhadap tekanan lingkungan baik dari darat maupun laut.

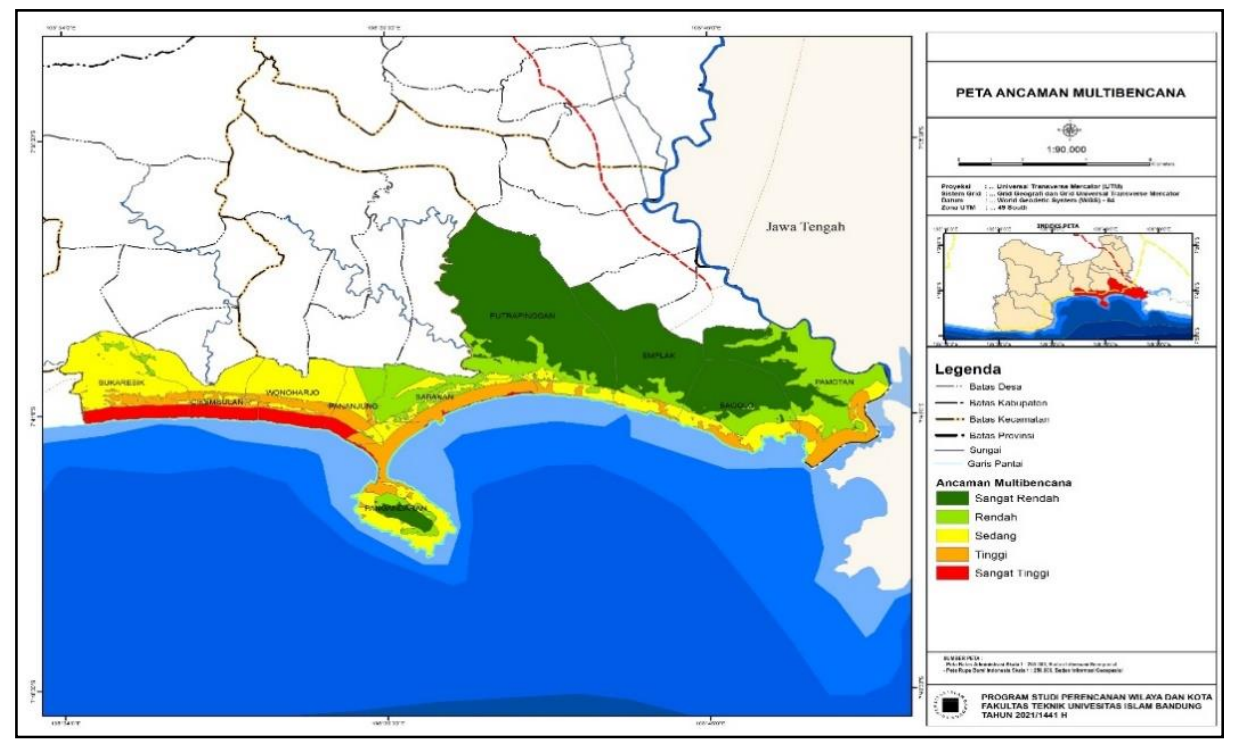

Gambar 4. Ancaman Multi Bencana

\section{Kerentanan Wilayah}

Kerentanan (vulnerability) merupakan suatu kondisi dari suatu komunitas atau masyarakat yang mengarah pada penurunan ketahanan akibat pengaruh eksternal yang mengancam kehidupan, mata pencaharian, sumber daya alam, infastruktur, produktifitas ekonomi dan kesejahteraan. Tingkat kerentanan wilayah yang sudah didapat selanjutnya dilakukan overlay dengan ancaman multibencana untuk mengetahui kerentanan wilayah tersebut terhadap kemungkinan bencana yang akan terjadi.

Tabel 5. Kerentanan Wilayah

\begin{tabular}{|l|l|r|r|r|r|r|c|}
\hline $\begin{array}{c}\mathbf{N} \\
\mathbf{0}\end{array}$ & \multicolumn{1}{|c|}{ Desa } & $\begin{array}{c}\text { Kerentana } \\
\mathbf{n} \text { Sosial }\end{array}$ & \multicolumn{1}{|c|}{$\begin{array}{c}\text { Kerentana } \\
\text { n Ekonomi }\end{array}$} & $\begin{array}{c}\text { Kerentana } \\
\text { n Fisik }\end{array}$ & $\begin{array}{c}\text { Kerentanan } \\
\text { Lingkunga } \\
\mathbf{n}\end{array}$ & $\begin{array}{c}\text { Tota } \\
\mathbf{l} \\
\text { Skor }\end{array}$ & $\begin{array}{c}\text { Kerentana } \\
\mathbf{n}\end{array}$ \\
\hline 1 & Babakan & 0.96 & 0.65 & 0.40 & 0.12 & 2.13 & Sedang \\
\hline 2 & Bagolo & 0.56 & 0.65 & 0.47 & 0.18 & 1.87 & Sedang \\
\hline 3 & Cikembulan & 0.96 & 0.75 & 0.32 & 0.10 & 2.14 & Sedang \\
\hline 4 & Emplak & 0.56 & 0.65 & 0.47 & 0.16 & 1.85 & Sedang \\
\hline 5 & Pamotan & 0.56 & 0.65 & 0.40 & 0.17 & 1.78 & Sedang \\
\hline 6 & Pananjung & 0.96 & 0.75 & 0.40 & 0.10 & 2.21 & Sedang \\
\hline 7 & Pangandaran & 0.96 & 0.45 & 0.25 & 0.18 & 1.84 & Sedang \\
\hline 8 & Putrapingga & 0.56 & 0.75 & 0.40 & 0.18 & 1.89 & Sedang \\
\hline 9 & n & & & & & & \\
\hline 10 & Wonaresik & 0.64 & 0.75 & 0.40 & 0.14 & 1.93 & Sedang \\
\hline
\end{tabular}

Sumber: Hasil Analisis, 2021 
Seluruh desa di wilayah kajian termasuk pada kerentanan wilayah sedang. Selanjutnya dilakukan analisis overlay terhadap ancaman multi bencana menggonakan metode matrik kerentanan dan di klasifikasikan menjadi 3 tingkan kerentanan yaitu rendah, sedang dan tinggi.

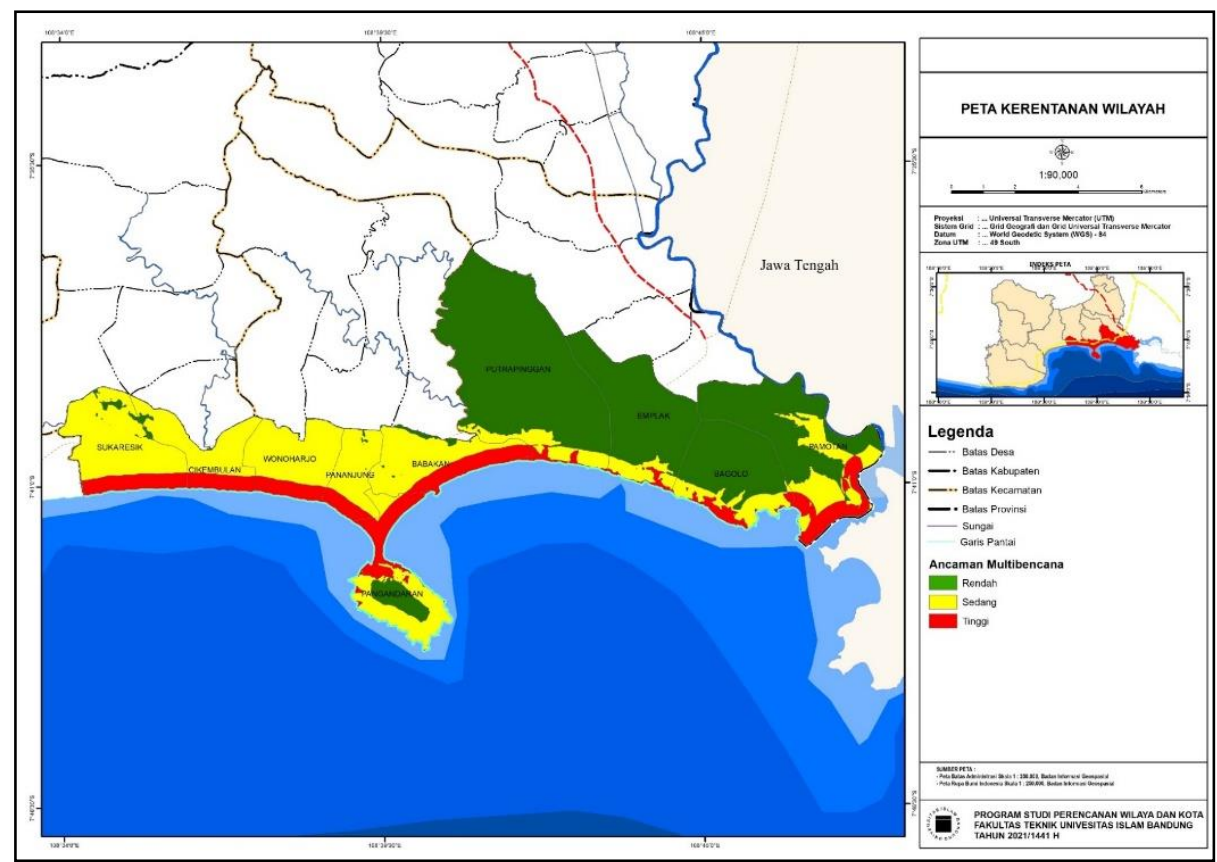

Gambar 5. Peta Kerentanan Multibencana

\section{Kerentanan Terhadap Pola Ruang}

Pada pola ruang Kabupaten Pangandaran didapat bahwa wilayah kajian memiliki tutupan lahan dengan peruntukan kawasan pemukiman sebesar $36.97 \%$ atau $2651 \mathrm{Ha}$ dari total luas kawasan budidaya. Sedangkan tutupan lahan lainnya di dominasi oleh perkebunan dan hutan produksi. Pada kawasan lindung sebesar $26.12 \%$ atau 548 Ha di tetapkan sebagai kawasan rawan tsunami tinggi, namun pada penggunaan lahan eksisting kawasan tersebut merupakan kawasan terbangun yang banyak berlangsung kegiatan perekonomian termasuk sektor pariwisata.

Tabel 6. Tingkat Kerentanan Terhadap Pola Ruang

\begin{tabular}{|c|c|c|c|c|c|}
\hline No & Pola Ruang & Kelas Kerentanan & Luas (Ha) & Persentase $(\%)$ & Total \\
\hline \multirow{3}{*}{1} & \multirow{3}{*}{ Kawasan Budidaya } & Rendah & 4161.78 & 58.04 & \multirow{3}{*}{$\begin{array}{c}7170.40 \mathrm{Ha} \\
(77.36 \%)\end{array}$} \\
\hline & & Sedang & 2790.39 & 38.92 & \\
\hline & & Tinggi & 218.23 & 3.04 & \\
\hline \multirow{3}{*}{2} & \multirow{3}{*}{ Kawasan Lindung } & Rendah & 473.90 & 22.59 & \multirow{3}{*}{$\begin{array}{c}2097.91 \mathrm{Ha} \\
(22.64 \%)\end{array}$} \\
\hline & & Sedang & 636.42 & 30.34 & \\
\hline & & Tinggi & 987.59 & 47.07 & \\
\hline
\end{tabular}

Sumber: Hasil Analisis, 2021

\section{Dampak kerentanan pantai terhadap wilayah pesisir}

Terkait dengan pengembangan wilayah Jawa Barat, dalam RTRW Provinsi diatur mengenai pembagian WP di Provinsi Jawa Barat. Sebagaimana pembagian WP yang dimaksud Kabupaten Pangandaran termasuk dalam WP Priangan Timur-Pangandaran yaitu sebagai penjabaran dari Kawasan Andalan Priangan Timur-Pangandaran dengan kesetaraan fungsi dan peran kawasan di KSN Pacangsanak (Pangandaran-Kalipucang-Segara Anakan). Dalam RTRW Kabupaten Pangandaran dijabarkan bahwa PKW yaitu wilayah yang termasuk dalam Kecamatan Pangandaran (RTRW Kabupaten Pangandaran, 2018). Arah pemanfaatan ruang yang dijabarkan antara lain :

1. Pengembangan pusat perbelanjaan skala nasional

2. Pengembangan pusat kesehatan skala regional 
3. Pengembangan pusat perdagangan skala regional

4. Pengembangan pusat pendidikan skala regional

5. Pengembangan pusat rekreasi, wisata, dan olahraga skala regional

6. Pengembangan fasilitas bisnis pariwisata berskala internasional Pangandaran

7. Pengembangan pusat bisnis perikanan dan kelautan

Tingkat kerentanan wilayah terhadap multi bencana yang terjadi dapat menjadi faktor yang dapat menghambat proses pengembangan wilayah itu sendiri, beberapa pusat kegiatan pada wilayah studi terdampak oleh kerentanan multi bencana dengan tingkat kerentanan yang berbeda seperti objek wisata, pelabuhan, pasar dan sebagainya seperti yang dapat dilihat pada peta berikut:

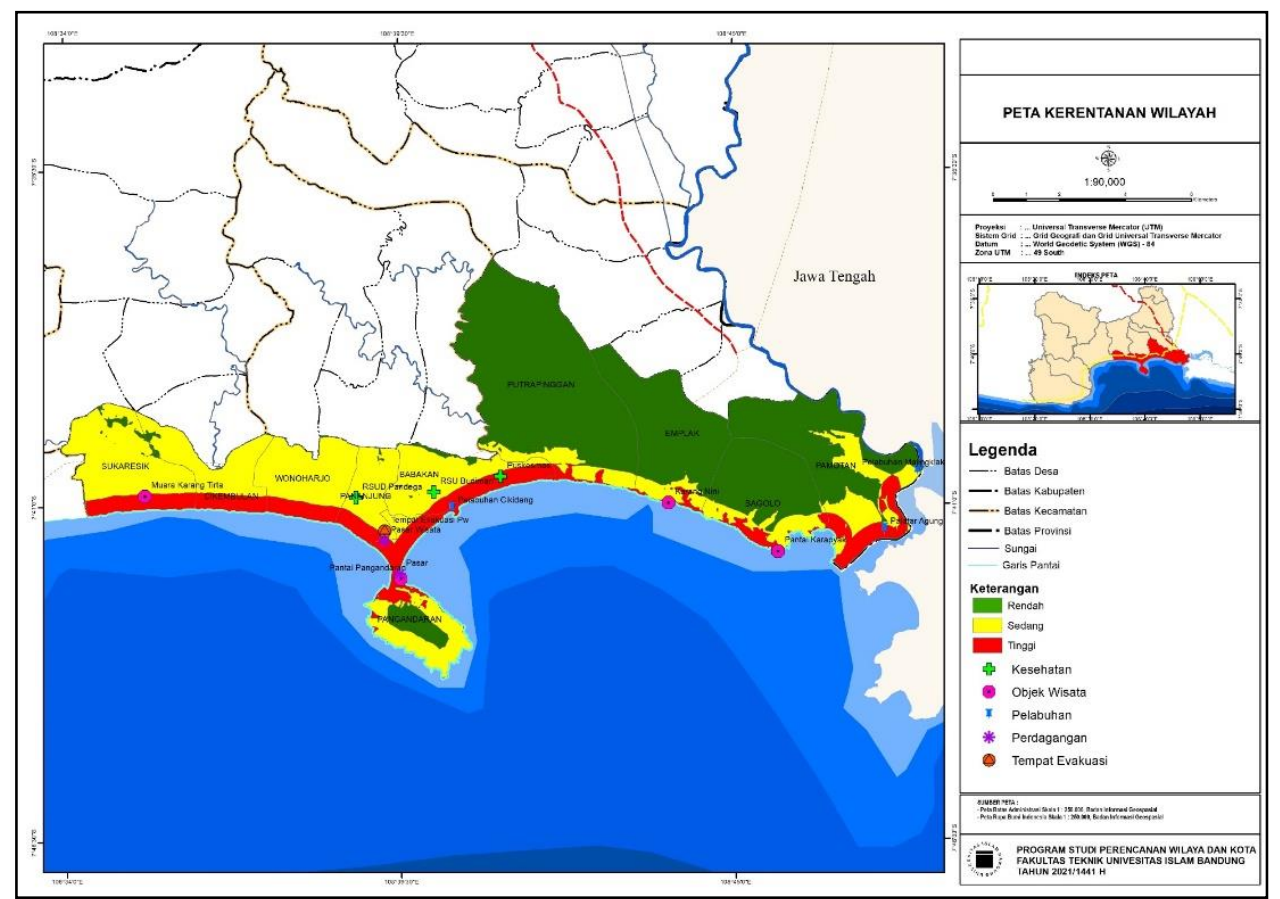

Gambar 6. Peta Kawasan Pengengembangan Wilayah Terhadap Kerentanan Multibencana

\section{Kesimpulan}

Berdasarkan kajian yang dilakukan pada penelitian ini dapat disimpulkan bahwa:

1. Tingkat kerentanan wilayah berdasarkan ancaman multibencana dalam studi ini dikategorikan menjadi 3 kelas yaitu kerentanan rendah, sedang dan tinggi. Wilayah dengan kategori kerentanan rendah memiliki persentase 50.02\% yang mendominasi di Desa Bagolo, Desa Emplak, Desa Putrapinggan dan sebagian Desa Pamotan. Tingkat kerentanan sedang memiliki persentase $36.97 \%$ yang tersebar di seluruh wilayah studi. Wilayah dengan tingkat kerentanan tinggi memiliki persentase $13.01 \%$, wilayah tersebut melingkupi Desa Babakan, Desa Cikembulan, Desa Pamotan, Desa Pananjung, Desa Pangandaran, Desa Sukaresik dan Desa Wonoharjo faktor yang membuat kerentanan tinggi pada wilayah tersebut antara lain wilayah yang rendah kurang dari $5 \mathrm{Mdpl}$, slope yang landai kurang dari $15 \%$ serta morfologi didominasi oleh daratan berpasir dan berlumpur. Pada wilayah dengan tingkat kerentanan tinggi terdapat faktor kerentanan sosial yang yang tinggi, terutama karena kepadatan penduduk yang lebih besar dibandingkan wilayah dengan tingkat kerentanan lainnya. Ditinjau dari pola ruang kawasan budidaya pada wilayah studi didominasi oleh tingkat kerentanan rendah dengan persentase $58.04 \%$, sedangkan kawasan lindung didominasi oleh tingkat kerentanan tinggi dengan persentase $47.07 \%$. 
Tabel 7. Kerentanan Wilayah Multi Bencana

\begin{tabular}{|r|l|r|r|r|}
\hline \multirow{2}{*}{ No } & \multirow{2}{*}{ DESA } & \multicolumn{3}{c|}{ Kerentanan } \\
\cline { 3 - 5 } & & \multicolumn{1}{c|}{ Rendah } & \multicolumn{1}{c|}{ Sedang } & \multicolumn{1}{c|}{ Tinggi } \\
\hline 1 & Babakan & 23.96 & 444.66 & 194.05 \\
\hline 2 & Bagolo & 630.00 & 174.11 & 73.89 \\
\hline 3 & Cikembulan & 14.77 & 384.81 & 107.90 \\
\hline 4 & Emplak & 891.26 & 106.36 & 27.09 \\
\hline 5 & Pamotan & 832.09 & 315.68 & 203.34 \\
\hline 6 & Pananjung & 3.02 & 290.12 & 74.34 \\
\hline 7 & Pangandaran & 131.66 & 353.32 & 210.18 \\
\hline 8 & Putrapinggan & 2075.90 & 182.95 & 41.64 \\
\hline 9 & Sukaresik & 29.05 & 675.52 & 164.77 \\
\hline 10 & Wonoharjo & 3.98 & 499.29 & 108.62 \\
\hline & Total & 4635.68 & 3426.82 & 1205.82 \\
\hline & Persen $(\%)$ & 50.02 & 36.97 & 13.01 \\
\hline
\end{tabular}

Sumber: Hasil Analisis, 2021

2. Dampak yang ditimbulkan dari tingkat kerentanan tersebut terhadap wilayah pesisir Pangandaran adalah terjadinya kerusakan hingga terganggunya kegiatan sosial ekonomi terutama pada tempat-tempat yang menjadi pusat pengembangan di wilayah Kabupaten Pangandaran seperti objek wisata dan pelabuhan.

\section{Acknowledge}

Dalam penyelesaian penelitian tugas akhir ini, saya ingin mengucapkan terimakasih kepada beberapa pihak yang membantu baik secara langung maupun tidak langsung:

1. Bapak Hani Burhanudin Ir. MT. selaku Ketua Program Studi Perencanaan Wilayah dan Kota Universitas Islam Bandung.

2. Ibu Astri Mutia E., Ir., MT.., selaku koordinator Tugas Akhir.

3. Ibu DR. Yulia Asyiawati, S. T., M. Si, selaku dosen pembimbing Tugas Akhir dan Dr. Dudi Nasrudin, S. T., M. T sebagai CO Pembimbing, yang telah membimbing dan memberi arahan kepada penulis selama proses penyusunan Tugas Akhir.

4. Seluruh staf pengajar Program Studi Perencanaan Wilayah dan Kota Universitas Islam Bandung yang telah memberikan ilmu, kritik, dan saran sebagai masukan dan memberi inspirasi kepada penulis dalam penyusunan Tugas Akhir ini.

\section{Daftar Pustaka}

[1] Aldrian, Edvin, Mimin Karmini, and Budiman. 2011. "Adaptation and Mitigation of Climate Change in Indonesia (Adaptasi Dan Mitigasi Perubahan Iklim Di Indonesia)." Pusat Perubahan Iklim dan Kualitas Udara BMKG (2): 174. www.bmkg.go.id.

[2] Alibasyah, M Rusli, and Abubakar Karim. 2013. "Land Degradation Due to Erosion on Agricultural Areas in Lembah Seulawah, Aceh Besar District." Jurnal Manajemen Sumberdaya Lahan 2(3): 240-49.

[3] Arifin, Zaenal. 2010. Pola Spasial Kerentanan Bencana Alam (Studi Kasus Kabupaten Cianjur). Tesis Magister Ilmu Geografi. Fakultas Matematika dan Ilmu Pengetahuan Alam. Universitas Indonesia.

[4] BNPB, N. D. M. A. of the R. of I.-. (2018). IRBI (Indeks Resiko Bencana Indonesia) Tahun 2018. Republik Indonesia. [4] Azwar, Syaifuddin. 2005. Metode Penelitian. Jogyakarta: Pustaka Belajar.

[5] Garia, M. P., \& Asyiawati, Y. (2019). Kajian Tingkat Kerentanan Bencana Banjir Bandang di Kecamatan Cipatujah Kabupaten Tasikmalaya. 